Jurnal Kependudukan Indonesia | Vol. 11 No. 1 Juni 2016 |39-48

JURNAL KEPENDUDUKAN INDONESIA

p-ISSN : 1907-2902 (Print)

e-ISSN : 2502-8537 (Online)

\title{
MEMUDARNYA NILAI KEARIFAN LOKAL MASYARAKAT DALAM PENGELOLAAN SUMBER DAYA AIR
}

\author{
(WANING VALUE OF LOCAL WISDOM IN \\ THE MANAGEMENT OF WATER RESOURCES)
}

\author{
Deny Hidayati \\ Pusat Penelitian Kependudukan, Lembaga Ilmu Pengetahuan Indonesia \\ Korespondensi penulis: gatsu.It10@yahoo.com
}

\begin{abstract}
Water is vital for human and thus it has to be made available for our life. Many communities in Indonesia, with their local knowledge, customs, and culture that are passed from generations, utilize water resources in their areas to meet daily needs. They manage the resources and live in harmony with the surrounding nature. The wisdom of community on water resource management, unfortunately, has experienced a shift. Water has then become an important issue that requires significant attention. This paper discusses shift in the value of local wisdom on water resources. Data and information in this paper is based on desk reviews from research/assessment results, books, documents and the author's field experiences in implementing relevant researches. The discussion focuses on the waning of local knowledge and wisdom as social capital in the provision of community water supply and as a form of their protection against water resources, such as the erosion of togetherness and mutual cooperation among members of the community, change in the value of water from social good to commercialization, the waning of local and traditional institutions, and the community's sense of belonging to their common property resources. This paper also analyze the shift of local wisdom's role in maintaining balance and harmony between the communities and their surrounding environment, and challenges to the existence of local wisdom associated with population pressures, modernization and development activities with less attention to the preservation of water resources and environment.
\end{abstract}

Keywords: Local wisdom, Community, Water Resource Management, Population Pressure, Economic and Development Activities

\begin{abstract}
Abstrak
Air merupakan kebutuhan vital manusia dan karena itu harus tersedia agar dapat bertahan hidup. Sebagian masyarakat Indonesia, dengan pengetahuan lokal, kebiasaan dan budaya yang telah diwariskan secara turun temurun, memanfaatkan sumber air di daerahnya untuk memenuhi kebutuhan sehari-hari mereka. Masyarakat mengelola sumber daya yang ada dan mereka hidup harmonis dengan alam dan lingkungan di sekitarnya. Kearifan lokal masyarakat dalam pengelolaan sumber daya air, sayangnya, telah memudar. Tulisan ini mendiskusikan pergeseran kearifan lokal sebagai modal sosial dalam pemenuhan kebutuhan air dan sebagai bentuk perlindungan masyarakat terhadap sumber daya air. Data dan informasi dalam tulisan ini merupakan hasil desk reviews dari berbagai laporan penelitian/kajian, buku dan dokumen serta pengalaman penulis ketika melakukan penelitian-penelitian yang relevan. Diskusi terfokus pada memudarnya nilai kearifan lokal masyarakat, seperti nilai kebersamaan dan gotong royong, bergesernya nilai air dari dimensi sosial ke arah komersialisasi ekonomi, lunturnya pranata lokal dan lembaga pengelolaan air tradisional, serta tergerusnya 'rasa' kepemilikan bersama terhadap sumber daya air di sekelilingnya. Tulisan ini juga mendiskusikan pergeseran fungsi kearifan lokal dalam 'menjaga' hubungan yang harmonis antara masyarakat dan alam, serta tantangan terhadap eksistensi kearifan lokal terutama yang terkait dengan tekanan penduduk, modernisasi dan kegiatan pembangunan yang kurang memperhatikan preservasi sumber daya air dan lingkungan.
\end{abstract}

Kata Kunci: Kearifan Lokal, Masyarakat, Pengelolaan Sumber Daya Air, Tekanan Penduduk, Kegiatan Ekonomi dan Pembangunan 


\section{PENDAHULUAN}

Air merupakan kebutuhan vital dalam kehidupan manusia dan mutlak harus tersedia untuk menunjang hidup dan kehidupannya. Masyarakat dengan pengetahuan, kebiasaan, dan budaya yang diwariskan secara turun menurun memanfaatkan sumber air di wilayahnya untuk memenuhi kebutuhan sehari-hari. Mereka mengelola sumber daya tersebut secara bersama-sama dan hidup harmonis dengan alam di sekitarnya.

Subak adalah salah satu contoh kearifan masyarakat dari Bali yang mengatur pergiliran dan pembagian air serta peraturan pola tanam. Pengaturan pemanfaatan air ini merupakan hasil musyawarah masyarakat yang didasarkan pada falsafah Tri Hita Karana. Falsafah masyarakat Bali ini menekankan pada asas keharmonisan, keseimbangan, dan keserasian hubungan antar sesama anggota masayarakat, masyarakat dengan lingkungan, serta masyarakat dengan Tuhan. Dalam kondisi air yang terbatas, pengaturan sangat diperlukan agar semua anggota masyarakat mempunyai akses untuk mendapatkan air sesuai dengan cara dan tempat yang disepakati bersama. Salah satu cara pengaturan air adalah masa gadon dimana wilayah subak dibagi menjadi dua kelompok, yaitu kelompok masa yang mendapat giliran air pada musim hujan dan kelompok gadon yang mendapat giliran air pada musim kemarau. Sedangkan pola tanam, jenis tanaman, dan jadwal kapan menanam ditentukan dan disepakati oleh pengurus dan anggota subak. (Aprianto dkk, 2008; Ardana, 2005; dan Sutawan, 2003).

Kearifan masyarakat dalam pengelolaan sumber daya air di Indonesia sayangnya banyak yang telah mengalami pergeseran. Kebutuhan akan air terus meningkat seiring dengan meningkatnya jumlah penduduk (dengan berbagai jenis kebutuhannya) dan kegiatan pembangunan yang kurang memperhatikan kelestarian sumber daya air dan lingkungan. Air saat ini telah menjadi masalah yang perlu mendapat perhatian serius dikarenakan penurunan kapasitas dan kualitas sumber daya air di sebagian besar wilayah negeri ini.

Tulisan ini mendiskusikan pergeseran nilai kearifan lokal masyarakat dalam pengelolaan sumber daya air di Indonesia. Pembahasan difokuskan pada memudarnya kearifan lokal sebagai modal sosial dalam pemenuhan kebutuhan air masyarakat, dan sebagai bentuk perlindungan masyarakat terhadap sumber daya air. Peran kearifan lokal dalam menjaga keseimbangan dan keharmonisan masyarakat dengan alam di sekitarnya menghadapi banyak tantangan. Kondisi ini berpengaruh terhadap eksistensi tatanan sosial masyarakat, utamanya dalam upaya pengelolaan sumber daya air secara berkelanjutan.

Data dan informasi yang digunakan dalam tulisan ini berasal dari dua sumber. Sumber pertama adalah dari hasil desk reviews berbagai hasil studi yang telah dikemas dalam artikel, laporan, dan buku serta dokumen-dokumen lain yang relevan dengan topik yang dibahas, yaitu kearifan masyarakat dalam pengelolaan sumber daya air di Indonesia. Sumber ke dua adalah pengalaman lapangan penulis ketika melakukan riset yang relevan, seperti kontribusi masyarakat: pengelolaan irigasi di Lahat, antara peningkatan degradasi versus kearifan lokal dalam pengelolaan DAS di Jambi, adaptasi orang Jawa di daerah Pasang Surut dan Dataran Tinggi Kalimantan Selatan dan Kalimantan Timur, adaptasi petani terhadap perubahan iklim dan degradasi sumber daya alam di Kota Batu dan Kabupaten Demak.

\section{Pengertian dan Makna Kearifan Lokal}

Kearifan lokal adalah tatanan sosial budaya dalam bentuk pengetahuan, norma, peraturan dan keterampilan masyarakat di suatu wilayah untuk memenuhi kebutuhan (hidup) bersama yang diwariskan secara turun temurun. Kearifan lokal merupakan modal sosial yang dikembangkan masyarakat untuk menciptakan keteraturan dan keseimbangan antara kehidupan sosial budaya masyarakat dengan kelestarian sumber daya alam di sekitarnya.

Definisi kearifan lokal bervariasi menurut referensi dan cakupannya, namun dari definisi-definisi tersebut terdapat beberapa kata kunci, yaitu: pengetahuan, gagasan, nilai, keterampilan, pengalaman, tingkah laku, dan kebiasaan adat yang dilakukan oleh masyarakat di wilayah tertentu (Keraf, 2002; Ardana, 2005; Aprianto dkk, 2008; Wahyu dalam Mukti, 2010; Yamani, 2011). Pengetahuan dan pengalaman masyarakat, menurut Sunaryo (2003), menyatu dengan sistem norma, kepercayaan, kebersamaan, keadilan yang diekspresikan sebagai tradisi masyarakat sebagai hasil abstraksi dan interaksinya dengan alam dan lingkungan di sekitarnya dalam kurun waktu yang lama. Kearifan lokal, karena itu menjadi pedoman dalam bersikap dan bertindak untuk memenuhi kebutuhan hidup sehari-hari masyarakat (Wardana, 2005).

Kearifan lokal sebagai modal sosial sangat penting dalam pengelolaan sumber daya air di suatu wilayah. Kearifan lokal mempunyai dua peran utama, yaitu: memenuhi kebutuhan air untuk hidup dan kehidupan masyarakat, dan menjaga hubungan yang harmonis 
antara masyarakat dengan sumber daya air dan lingkungan di sekitarnya.

Kearifan lokal mencakup lima dimensi sosial, yaitu pengetahuan lokal, budaya lokal, keterampilan lokal, sumber-sumber lokal, dan proses sosial lokal (Aprianto dkk, 2008). Kelima dimensi ini mereka gambarkan dalam pengelolaan air DAS Citanduy dan Subak Bali sebagai berikut.

- Pengetahuan lokal tentang pembuatan aliran air dari bambu dan penanaman pohon dadap dan kiara oleh masyarakat Desa Bingkeng DAS Citanduy, dan pembuatan bangunan penangkap air sungai yang diletakkan pada bagian ujung sungai oleh petani Subak di Bali.

- Budaya lokal berupa larangan (tabu dan pamali) oleh masyarakat di DAS Citanduy, dan konsep Tri Hita Karana oleh masyarakat (Subak) di Bali.

- Keterampilan lokal berupa pembuatan aliran air di DAS Cintanduy, dan pembuatan bangunan penangkap air/empelan yang dapat disesuaikan bila diperlukan di Subak Bali.

- Sumber lokal dengan pemanfaatan potensi lokal, seperti pohon dadap di DAS Citanduy, dan terowongan irigasi dibuat melengkung mengandalkan kekuatan batuan asli di Subak.

- Proses sosial lokal berupa keramatisasi pengelolaan sumber daya air di DAS Citanduy, dan upacara ritual sebelum pekerjaan di sawah dimulai di Subak Bali.

Masyarakat memenuhi kebutuhan airnya dengan memanfaatkan dan mengelola sumber daya air yang ada di wilayahnya, sesuai dengan kearifan lokal yang dipraktikkan secara turun temurun. Bentuk atau jenis kearifan lokal bervariasi menurut kelompok masyarakat dan wilayah, namun sebagai modal sosial, kearifan lokal memiliki nilai universal yang sama, yaitu gotong royong dan tolong menolong untuk mendapatkan air dan menjaga kelestarian sumber dayanya.

Eksistensi kearifan lokal dalam pengelolaan sumber daya air di Indonesia, sayangnya, telah mengalami penurunan. Kondisi ini digambarkan dari banyaknya nilai-nilai kearifan lokal yang sudah tidak dipraktikkan lagi, dan di banyak tempat, keberadaan kearifan lokal sudah 'diabaikan' dan tinggal menjadi cerita masyarakat. Di beberapa tempat lainnya, kearifan lokal bahkan telah hilang. Masyarakat, terutama generasi muda sudah tidak mengetahui lagi adanya kearifan lokal di daerahnya, hanya ada satu atau dua 'sesepuh' anggota masyarakat yang mengetahui namun karena faktor usia (sudah tua) dan kesehatan, beliau sudah tidak dapat menjelaskannya dengan lengkap dan baik. (penjelasan dengan contoh-contoh yang lebih detail dapat dibaca pada bagian selanjutnya).

Pergeseran nilai sosial kearifan lokal digambarkan dari memudarnya tatanan yang disepakati masyarakat dan dipraktikkan oleh anggota masyarakat secara besamasama. Bentuk pergeseran bervariasi menurut kelompok masyarakat dan daerah, seperti keberadaan sumber air, waktu pengambilan air, kalender yang mengatur ketersediaan air dan kecepatan/arah angin sesuai musim (hujan/kemarau) dengan kegiatan pertanian dan kenelayanan (contoh-contoh lihat penjelasan selanjutnya).

\section{Memudarnya Nilai Kebersamaan dan Gotong Royong}

Nilai-nilai yang terkandung dalam kearifan lokal sarat dengan makna kebersamaan dan mempunyai fungsi sosial dan ekologi yang tinggi dalam pengelolaan sumber daya air secara berkelanjutan. Tetapi, fungsi sosial ekologi ini telah bergeser ke arah fungsi ekonomi. Hal ini diindikasikan oleh memudarnya kebersamaan dalam mengelola air, memudarnya kebiasaan gotong royong dan sebaliknya tumbuh kembangnya nilai ekonomi dari air.

Padahal, gotong royong dan tolong menolong merupakan kebiasaan budaya masyarakat Indonesia (Baiquni, 2009; dan Ikaputra, 2009). Gotong royong adalah kegiatan yang dilakukan masyarakat secara bersama-sama untuk memenuhi kebutuhan bersama (publik) yang sifatnya sukarela. Sedangkan tolong menolong biasanya dilakukan antar anggota masyarakat untuk keperluan perseorangan (individual) yang dilaksanakan untuk tujuan-tujuan tertentu, seperti pembangunan saluran air ke rumah dan pembangunan rumah.

Memudarnya kebersamaan dan kegiatan gotong royong dialami masyarakat di sebagian besar masyarakat Indonesia. Di Kalimantan Tengah, misalnya, masyarakat dulunya membuat dan memelihara handil (berupa parit atau sungai kecil di daerah pasang surut) secara bersama-sama, namun kegiatan ini telah memudar. Padahal kearifan masyarakat ini sangat diperlukan, karena handil mempunyai multi fungsi, seperti: saluran untuk mengairi sawah, jalur transportasi air masyarakat dari permukiman ke sawah atau ladang/kebun dan ke hutan untuk mengambil hasil hutan yang dibutuhkan masyarakat untuk kehidupan sehari-hari, dan tempat MCK (mandi, cuci dan kakus). (Octora dkk, 2010). 
Dengan memudarnya nilai kebersamaan dan kegiatan gotong royong, maka kegiatan masyarakat untuk kepentingan bersama, seringkali dilakukan dengan kompensasi, umumnya dalam bentuk 'uang'. Anggota masyarakat yang terlibat dengan demikian menjadi 'pekerja' dalam kegiatan tersebut. Solidaritas sosial masyarakat semakin berkurang dengan dibagikannya bantuan-bantuan, baik dalam bentuk tunai maupun barang, yang dilakukan oleh pemerintah maupun pada donor. Pembagian dan pemberian kompensasi atau peng'upah'an kegiatan untuk kepentingan masyarakat ini tidak hanya melunturkan tatanan sosial yang ada, tetapi juga berpotensi menimbulkan perselisihan antar anggota masyarakat.

\section{Bergesernya Nilai Air dari Dimensi Sosial ke Dimensi Ekonomi}

Memudarnya kearifan lokal masyarakat berkaitan erat dengan bergesernya orientasi masyarakat terhadap nilai air dan sumber daya alam, yaitu dari dimensi sosial ke dimensi ekonomi. Air yang semula dimanfaatkan secara 'gratis' tanpa adanya kompensasi, ternyata mempunyai nilai ekonomi dan nilai ini semakin tinggi dari waktu ke waktu. Komersialisasi terhadap air tumbuh dan berkembang seiring dengan semakin banyaknya volume air yang dibutuhkan masyarakat dan bervariasinya jenis kebutuhan terhadap sumber daya tersebut. Kondisi ini terutama terjadi karena sumber daya air semakin terbatas dan sebaliknya kebutuhan akan air semakin tinggi. Selain itu, nilainya akan semakin tinggi dengan meningkatnya kegiatan pembangunan dan investasi di kawasan sumber air tersebut.

Akibatnya, masyarakat yang dulunya mendapatkan air secara gratis sekarang 'harus' mengeluarkan 'uang'. Mereka mengeluarkan uang 'membeli' air untuk konsumsi (minum dan masak) serta keperluan lainnya. Meskipun akses terhadap air relatif mudah dan ketersediaan air juga berlimpah, dengan memudarnya kebersamaan dan gotong royong dalam penyediaan air, dan menurunnya kualitas air, maka masyarakat harus berupaya untuk menyediakan air sendiri-sendiri atau menggunakan jasa perorangan atau perusahaan, seperti jasa pedagang air keliling dan air galon, Perusahaan Air Minum (PAM) atau Perusahaan Daerah Air Minum (PDAM). Masuknya proyek Penampungan Air Hujan $(\mathrm{PAH})$ dan proyek pipa air minum PDAM di Telaga Omang dan Ngeloro di Yogyakarta, misalnya, menyebabkan runtuhnya larangan pengambilan air telaga pada malam hari, karena kebutuhan air masyarakat sekarang dipasok melalui PDAM.

\section{Lunturnya Pranata Lokal dan Tergerusnya Lembaga Pengelola Air Tradisional}

Menurunnya penggunaan pronoto mongso (merupakan tatanan yang mengatur kegiatan pertanian masyarakat Jawa) merupakan contoh lunturnya aturan lokal. Pronoto mongso merupakan sistem kalender musim yang digunakan petani dalam mengatur usaha taninya. Musim atau mongso, yang selama ini diyakini merefleksikan ketersediaan air dan waktunya dapat diperhitungkan oleh petani, telah digantikan oleh kemajuan teknologi melalui sistem irigasi teknis yang dapat berfungsi sepanjang tahun. Penggunaan teknologi sayangnya berimplikasi pada biaya yang harus ditanggung oleh petani sebagai kompensasi ketersediaan air di lahan pertaniannya.

Memudarnya nilai kearifan lokal masyarakat dalam pengelolaan sumber daya air juga berkaitan dengan lunturnya kelembagaan tradisional yang digantikan oleh kelembagaan resmi yang umumnya dikembangkan oleh pemerintah, seperti Persatuan Petani Pemakai air (P3A). Perubahan ini menyebabkan berubahnya pengelolaan air dari semula berbasis 'nilai dan tradisi' dalam masyarakat yang dipadukan dengan keselarasan hidup dengan alam di sekitarnya, menjadi pengelolaan yang berbasis 'hubungan struktural' yang merupakan hubungan relasi kekuasaan, misalnya pemerintah dari instansi yang terkait, pengurus dan anggota P3A serta masyarakat lainnya.

Lunturnya kelembagaan handil (merupakan kelembagaan masyarakat yang mengurus saluran air) di daerah pasang surut berkairan erat dengan dibangunnya saluran tersier di lokasi pasang surut oleh pemerintah. Kondisi ini bertolak belakang dengan tujuan pemerintah untuk lebih mengoptimalkan peran handil dengan dibangunannya saluran dan sistem irigasinya (teknis atau setengah teknis). Kawasan pengairan dengan sistem irigasi dengan demikian akan lebih luas dan air akan terdistribusi dengan lebih baik. Pembangunan saluran air pada kenyataannya merubah pengelolaan air di wilayah pasang surut tersebut, dari kelembagaan masyarakat yang diketuai oleh kepala handil menjadi kelembagaan yang dibentuk secara resmi oleh pemerintah seperti P3A. Meskipun pengurus P3A adalah wakil dari masyarakat, perubahan sistem dalam pengelolaan handil juga berimplikasi pada bentuk dan cara dalam pengelolaan yang sifatnya lebih resmi dengan aturan tugas dan kewajiban yang resmi dan rigid juga. 


\section{Memudarnya Rasa Kepemilikan terhadap Sumber Daya Milik Komunal}

Sumber daya air, di daerah-daerah yang kearifan lokalnya masih berjalan, merupakan hak milik komunal setiap anggota masyarakat hukum adat atau dikenal dengan common property resources. Konsep common property resources adalah konsep universal mengingat air dibutuhkan oleh semua orang dan sumber daya air merupakan bagian dari wilayah (hutan) yang dimiliki secara bersama dengan segala kewajiban yang melekat pada semua anggota masyarakat. Rasa 'memiliki' masyarakat terhadap sumber daya ini sangat tinggi dan karena itu mereka bertanggung jawab untuk menjaga dan melindunginya dari gangguan atau eksploitasi pihak luar.

Common property resources mengalami pergeseran dari pengelolaan oleh masyarakat beralih kepada pemerintah atau stakeholders lain. Pengalihan hak pengaturan hutan dari komunitas adat kepada pemerintah merupakan satu alasan penting memudarnya rasa memiliki atau sense of belonging masyarakat. Kondisi ini berimplikasi pada berkurangnya rasa tanggung jawab yang terpatri dalam kearifan lokal masyarakat.

Yamani (2011) mengemukakan memudarnya kearifan lokal masyarakat adat di Bengkulu disebabkan oleh perubahan sistem pemerintah dari Marga menjadi Desa sebagai implikasi dari berlakunya Undang-Undang No. 5 Tahun 1979 tentang Pemerintahan Desa. Perubahan sistem pemerintahan ini berpengaruh signifikan terhadap tatanan pengaturan kehidupan masyarakat dan berdampak pada lunturnya hukum lokal komunitas adat di Bengkulu. Masyarakat yang semula taat pada peraturan adat dan berpartisipasi aktif dalam memelihara hutan, termasuk sumber daya air, sekarang sudah mengabaikannya. Mereka mengeksploitasi sumber daya hutan dan air sesuai dengan kebutuhan dan kemampuan masing-masing tanpa mempertimbangkan kelestarian sumber daya tersebut.

\section{MEMUDARNYA FUNGSI KEARIFAN LOKAL DALAM 'MENJAGA' HUBUNGAN YANG HARMONIS DENGAN ALAM}

Kearifan lokal juga berfungsi sebagai tatanan masyarakat dalam menjaga hubungan yang harmonis dengan sumber daya air dan lingkungan di sekitarnya. Hubungan yang harmonis ini berdampak pada perlindungan fungsi sumber daya air dan keseimbangan lingkungan untuk mencapai pengelolaan secara berkelanjutan. Hubungan ini digambarkan dari beberapa sistem nilai dalam kearifan lokal, seperti pengkeramatan, pamali, dan tabu yang mempunyai makna sebagai 'peraturan' dan 'larangan' bagi masyarakat untuk melakukan tindakan yang dapat mengganggu atau merusak suatu kawasan/wilayah tertentu.

Di beberapa desa di DAS Citanduy, seperti di Desa Bingkeng dan Desa Batulawang, terdapat beberapa tempat yang 'dikeramatkan' pada setiap dusunnya. Masyarakat di tempat-tempat keramat tersebut tidak boleh, 'tabu', atau 'pamali' melakukan kegiatan ekonomi atau aktifitas lainnya. Dengan demikian, sumber daya air dan ekosistem di tempat-tempat yang dikramatkan ini 'dijaga dan dilindungi' oleh masyarakat atau secara implisit tempat-tempat tersebut menjadi daerah 'konservasi'.

Sistem nilai pada kearifan lokal yang berfungsi sebagai 'pelindung' sumber daya air, seperti 'pengkeramatan, tabu dan pamali', sayangnya banyak yang telah ditinggalkan masyarakat. Peraturan dan larangan dalam sistem nilai tersebut mungkin di'anggap' sebagai pembatasan bagi masyarakat dalam pemanfaatan sumber daya air dan lingkungan di sekitarnya.

Tabu atau larangan dulunya juga dipraktikkan oleh komunitas adat suku Lembak Delapan di Bengkulu. Mereka menamakan tabu sebagai tanjung kerapusan, suak uluh tulung, tinjau terkukuh, tanam tukuh, dan aturan adat utan tiga ragi. Tabu berlaku untuk pengelolaan hutan secara berkelanjutan, termasuk pengelolaan sumber daya air di kawasan hutan, seperti larangan menebang pohon di sekitar sumber atau mata air, membuka ladang di sekitar mata air dan di lereng atau cekungan yang rawan erosi dan longsor, serta penguasaan sumber air secara individual karena sumber air tersebut merupakan milik bersama masyarakat. Memudarnya kearifan lokal masyarakat adat di Bengkulu dalam melindungi sumber daya air berdampak pada upaya mereka melindungi hutan, karena sumber daya air merupakan bagian dari kawasan hutan. Padahal, masyarakat dulunya mempunyai kesepakatan untuk melindungi hutan dan memperhatikan larangan bagi setiap anggota masyarakat (Yamani, 2011).

Hasil studi Sulastriyono (2009) di Telaga Omang dan Ngeloro, Desa Planjan, Yogyakarta, juga menginformasikan lunturnya praktik kearifan lokal di daerah tersebut. Larangan menebang pohon sudah tidak diindahkan lagi oleh masyarakat setempat. Pohonpohon besar di sekitar telaga telah ditebang tahun 2003 ketika pemerintah melakukan renovasi telaga tanpa memperhatikan kearifan lokal yang ada. Padahal pohon-pohon tersebut berfungsi sebagai penyerap air 
dan air tanah juga mengalir ke telaga. Pohon-pohon besar di pinggir Telaga Ngeloro digantikan dengan tanggul yang terbuat dari beton/semen. Air tanah akibatnya tidak dapat meresap ke telaga dan bangunan tersebut bahkan menutup sebagian mata air. Akibatnya, telaga sekarang hanya berfungsi sebagai penampung air hujan pada musim hujan, karena mata airnya telah mati, tertutup semen tanggul. Padahal, menjamin peresapan air sebanyak-banyaknya kedalam tanah, menurut Soeprobowati (2010) merupakan upaya konkrit dari pengelolaan sumber daya air secara berkelanjutan.

Memudarnya kearifan lokal sangat disayangkan karena dalam pengelolaan air, kearifan lokal mengandung nilai pelestarian sumber daya. Masyarakat memahami bagaimana seharusnya mengatur keseimbangan dalam pemanfaatan dan pelestarian sumber daya air melalui larangan.

Masyarakat di Telaga Omang, Ngeloro, Kecamatan Saptosari, Yogyakarta mengetahui banyak larangan untuk melindungi air telaga, namun larangan tersebut kebanyakan juga sudah diabaikan. Mereka dilarang untuk menebang pohon-pohon besar/tertentu (seperti beringin, asem, widoro, preh, elo dan gayam) di sekitar telaga yang menjadi sumber air. Mereka juga tidak diperbolehkan mengambil air di telaga pada malam hari (jam 19.00 - 24.00), memancing ikan sebelum panen (musim kemarau), dan menangkap binatang liar di sekitar telaga. Mereka juga dilarang membuang sampah di sekitar telaga (Sulastriyono, 2009).

Larangan-larangan yang disepakati dalam kearifan lokal sangat erat kaitannya dengan upaya menjaga telaga agar dapat dimanfaatkan secara berkelanjutan dan terjaga kelestarian ekosistemnya. Namun informasi di atas mengemukakan bahwa banyak larangan yang sudah tidak dipatuhi lagi oleh masyarakat setempat dan/atau orang/pengusaha dari luar. Padahal, keberadaan pohon-pohon besar seperti beringin dan asem, misalnya, mempunyai peran penting dalam menyerap air dan melindungi sumber air di telaga. Mengambil air pada malam hari berkaitan dengan upaya menjaga ketersediaan air dan keselamatan dalam pengambilan air. Larangan memancing ikan sebelum waktu panen sangat penting untuk memberi kesempatan ikan di telaga untuk tumbuh dan berkembang agar dapat dimanfaatkan (produksi) secara berkelanjutan.

Sedangkan larangan pembuangan sampah sarat dengan makna menjaga telaga atau sungai dari pencemaran, yang menjadi salah satu masalah penting dalam pengelolaan sumber daya air secara berkelanjutan. Pentingnya budaya bersih dalam kearifan lokal di beberapa daerah sangat ditekankan. Larangan untuk membuang sampah bagi masyarakat di Telaga Omang dan Ngeloro, Gunung Kidul, Yogyakarta dulu memang ditaati, tetapi sekarang sudah dilanggar, diindikasikan dari banyaknya sampah plastik di sekitar telaga (Sulastriyono, 2009).

Kearifan lokal dalam pengelolaan air juga berkaitan dengan pengaturan pembagian air dalam kegiatan pertanian, seperti handil di Kalimantan dan Subak di Bali. Handil berfungsi sebagai saluran irigasi dan drainase di lahan sawah di daerah pasang surut. Pengaturan handil sangat diperlukan mengikuti waktu pasang dan surutnya air laut. Sedangkan pengaturan air dalam kegiatan Subak di Bali mengacu pada ketersediaan air musim hujan dan musim kemarau (Octora dkk, 2010; Sutawan, 2003 dalam Aprianto dkk, 2008). Pengaturan air baik di handil maupun subak berorientasi pada proses alam, bagaimana mengatur pemanfaatan air sesuai atau harmoni dengan kondisi alam dan lingkungan di sekitarnya.

\section{TANTANGAN TERHADAP EKSISTENSI KEARIFAN LOKAL MASYARAKAT}

Kearifan lokal dalam pengelolaan sumber daya air idealnya perlu terus dipraktikkan, namun tatanan sosial ini, seiring dengan perkembangan dan perjalanan waktu, menghadapi banyak tantangan, sehingga mempengaruhi eksistensinya. Kondisi ini disebabkan oleh banyak faktor, terutama yang berkaitan dengan tekanan penduduk terhadap sumber daya air dan alam di sekitarnya, kegiatan pembangunan, dan modernisasi. Pawitan (2011) dan Ryadi (2012) mengungkapkan bahwa sumber daya air di Indonesia telah mengalami degradasi, diindikasikan dari penggunaan air yang berlebihan, meningkatnya pencemaran air, serta ancaman kekeringan pada musim kemarau dan banjir pada musim hujan. Permasalahan semakin kompleks dengan terjadinya konflik kepentingan antar stakeholders terkait dengan sumber daya air di wilayah bagian hulu dan/atau hilir, degradasi sungai, dan danau serta erosi tanah.

\section{Tekanan Penduduk}

Tekanan penduduk terhadap sumber daya air berkaitan erat dengan peningkatan jumlah dan mobilitas penduduk, dan perilaku mereka dalam pengelolaan sumber daya tersebut. Peningkatan jumlah dan mobilitas penduduk berkaitan dengan aspek kuantitas, berupa peningkatan kebutuhan air untuk konsumsi dasar (minum, makan, dan MCK) dan kehidupan lainnya. Peningkatan ini juga berkaitan dengan aspek kualitas, terutama perilaku masyarakat yang 
menyebabkan degradasi sumber daya dan pencemaran air.

\section{Peningkatan Jumlah Penduduk dan Keterbatasan Ketersediaan Air}

Indonesia mempunyai populasi penduduk yang sangat besar, menduduki posisi nomor empat di dunia, yaitu setelah China, India, dan Amerika Serikat. Jumlah penduduk meningkat dengan pesat dari 179,38 juta jiwa tahun 1990 menjadi 205,13 juta jiwa tahun 2000 dan 237,56 juta jiwa tahun 2010, meskipun tingkat pertumbuhan penduduknya cenderung mengalami penurunan dari 1,49 persen antara 1990-2000 turun jadi 1,2 antara 2000-2010 (BPS, 2013). Penduduk Indonesia diperkirakan akan meningkat menjadi 273,22 juta jiwa pada tahun 2025 (Bappenas, BPS dan United Nations Population Fund, 2013).

Tingginya perkembangan jumlah penduduk Indonesia berimplikasi pada besarnya peningkatan kebutuhan akan air, baik untuk konsumsi maupun kebutuhan lainnya. Air tidak hanya mempunyai fungsi sosial yang dapat dimanfaatkan semua orang, tetapi juga menjadi komoditas ekonomi yang diperlukan oleh rumah tangga, kegiatan pertanian, industri, infrastruktur, transfortasi, dan jasa (Manik, 2009; dan Suparmoko, 2008).

Meskipun sebagian besar wilayah Indonesia adalah air, hampir semua kota di Indonesia memiliki masalah besar tentang ketersediaan air dan pemenuhan kebutuhan air bagi penduduknya. Penduduk merupakan pengguna air terbanyak. Menurut standar WHO, kebutuhan air bersih penduduk sebanyak $2.000 \mathrm{~m}^{3}$ per orang per tahun. Sedangkan cadangan air di Indonesia, menurut Kementerian Riset dan Teknologi tahun 2007 sebesar $1.700 \mathrm{~m}^{3}$ per orang. Data ini menggambarkan bahwa menurut standar kebutuhan Indonesia masih kekurangan air bersih.

Kondisi ini juga dijelaskan oleh Bappenas, sekitar 100 juta penduduk Indonesia tahun 2013 belum bisa menikmati air minum yang aman menurut standar kesehatan. Jumlah ini jauh lebih besar, hampir dua kali lipat, jika dibandingkan dengan tahun 2008 ketika UNICEF menginformasikan sebanyak 55 juta orang Indonesia tidak mempunyai akses terhadap air bersih. Sebagian besar penduduk Indonesia, sekitar 70 persen, mengkonsumsi air dari sumber-sumber yang tercemar (ADB, 2006). Informasi minimnya ketersediaan air bersih bagi penduduk negeri ini juga dikemukakan oleh Direktur Permukiman dan Perumahan Bappenas yang mengatakan hanya 55,4 persen penduduk Indonesia yang dapat mengakses air minum yang layak tahun
2011 dan hanya meningkat 1,6 persen (menjadi 57,0 persen) tahun 2012.

Gambaran memprihatinkan yang serupa juga terjadi pada sanitasi lingkungan. Menurut Bappenas, sekitar 100 juta penduduk Indonesia tidak memiliki akses terhadap sanitasi. Jumlah ini jauh lebih besar dari data UNICEF tahun 2008 ketika 69 juta tidak memiliki akses untuk sanitasi. Sedangkan menurut Direktur Permukiman dan Perumahan Bappenas penduduk Indonesia yang dapat mengakses sanitasi hanya 55,6 persen tahun 2011 dan meningkat sedikit menjadi 57,2 persen tahun 2012. Kondisi ini masih dibawah target MDGs tahun 2015, yaitu 68,8 persen untuk air minum dan 62,4 persen untuk sanitasi.

Selain itu, peningkatan jumlah penduduk juga berimplikasi pada meningkatnya kebutuhan akan lahan untuk area permukiman, lahan pertanian, industri, serta sarana dan prasarana lain yang mendukung kehidupan. Besarnya alih fungsi lahan berkorelasi dengan besarnya eksploitasi air tanah yang berakibat pada penurunan kuantitas dan kualitas air tanah dan intrusi air laut.

\section{Masih Terbatasnya Perilaku dan Budaya Bersih}

Perilaku masyarakat berkaitan dengan kebersihan dan sanitasi lingkungan juga berpengaruh terhadap ketersediaan dan kualitas air. Budaya bersih di sebagian masyarakat masih minim, digambarkan dari perilaku masyarakat yang membuang sampah secara sembarangan. Selain itu, sebagian masyarakat juga masih membuang air besar (BAB) secara sembarangan, sekitar 41 juta orang setiap harinya (Kompas, 23 Juni 2013). Perilaku buang sampah dan BAB secara sembarangan ini menyebabkan pencemaran air. Pencemaran menjadi salah satu masalah penting dalam pengelolaan air secara berkelanjutan.

Kebiasaan membuang sampah sembarangan, selain menyebabkan pencemaran, juga seringkali menyumbat dan merusak jaringan atau saluran air yang mengakibatkan terjadinya banjir. Banyaknya sampah mengakibatkan rusaknya sejumlah saluran irigasi, terutama pada musim hujan, karena saluran air kapasitasnya tidak kuat menampung material sampah dan air. Sampah yang menumpuk di saluran air juga mengakibatkan tersendatnya aliran air dan karenanya sering menyebabkan banjir pada musim hujan dan sebaliknya kekeringan pada musim kemarau.

\section{Kegiatan Pembangunan dan Modernisasi}

Kegiatan pembangunan dan modernisasi teknologi dan informasi menurut banyak referensi berpengaruh 
signifikan terhadap eksistensi kearifan lokal (Keraf, 2002; Sulastriyono, 2009; Yamani, 2011). Percepatan laju pembangunan di segala sektor menyebabkan terjadinya pergeseran paradigma dalam pengelolaan sumber daya air. Pergeseran nilai terjadi semakin cepat karena pembangunan berfokus pada pertumbuhan ekonomi dan kurang memperhatikan tatanan sosial dalam masyarakat dan fungsi ekologi dari kearifan lokal masyarakat.

Pembangunan yang mengandalkan eksploitasi sumber daya alam mempercepat laju degradasi sumber daya air. Penebangan hutan dan alih fungsi lahan yang dilakukan secara berlebihan dan sembarangan menyebabkan rusaknya sumber daya air. Kondisi ini mengakibatkan penurunan daya dukung sumber daya air dan lingkungan di sekitarnya, dan tingginya fluktuasi debit air pada musim hujan dan musim kemarau.

Eksploitasi sumber daya alam yang berlebihan menyebabkan rusaknya daerah aliran sungai (DAS), baik di bagian hulu maupun hilir. Pohon-pohon pelindung sumber-sumber air terus ditebang sehingga mengganggu peresapan air ke dalam tanah dan berkurangnya debit air di sumber atau mata air. Kondisi ini juga menyebabkan terjadinya erosi tanah, sedimentasi, banjir pada musim hujan dan kekeringan pada musim kemarau. Konsekuensinya, kompetisi masyarakat dalam memanfaatkan air semakin tinggi, sehingga sangat potensial menimbulkan konflik antar stakeholders (Adnyana, 2003, Hidayati dkk, 2012).

Kerusakan hutan dan penyusutan vegetasi penutup tanah masih terus berlangsung. Menurut the World Resource Institute tahun 2015 Indonesia kehilangan tutupan hutan sekitar satu juta hektar pada 2013 dan hutan primer seluas $8.400 \mathrm{~km}^{2}$ tahun 2012. Kondisi ini berimplikasi pada menurunnya pasokan air secara signifikan, baik untuk konsumsi maupun pengembangan sektor pertanian yang sangat berpengaruh terhadap ketahanan pangan.

Pemerintah atas nama pembangunan sering mengabaikan pengetahuan dan kearifan lokal dalam pengelolaan sumber daya air yang telah dilakukannya secara turun temurun. Hal ini diindikasikan oleh upayaupaya pemerintah, seperti dalam meningkatkan produksi padi melalui teknologi dan subsidi harga untuk pupuk dan pestisida/herbisida (Dick, 1982; Fox, 1991; Mears, 1984), dan mengontrol harga beras serta pembangunan infrastruktur, terutama sistem irigasi (Collier et al, 1982; Dick, 1982; Fox, 1991). Akibatnya, pengelolaan air mengalami perubahan dari oleh masyarakat menjadi oleh pemerintah dengan pendekatan top-down. Akibatnya, banyak sistem nilai dalam pengelolaan sumber daya air dan tataguna air untuk pertanian yang telah dilakukan masyarakat secara turun temurun terancam oleh modernisasi pembangunan sistem irigasi dan kegiatan pembangunan lainnya.

Pengelolaan air, dengan pengembangan sistem irigasi, beralih dari masyarakat kepada pemerintah. Pada mulanya, masyarakat dengan kearifan lokal yang ada bergotong royong membuat saluran dan mengatur pergiliran air sesuai dengan kondisi dan kebutuhan petani, namun dalam sistem irigasi, pemerintah membangun saluran irigasi menggunakan teknologi dan mengatur pengelolaannya, misalnya melalui P3A. Perubahan sistem ini sangat mempengaruhi tatanan yang berkembang di masyarakat, yang semula berdimensi sosial budaya bergeser menjadi ekonomi berbasis teknologi.

Kemajuan teknologi di bidang pertanian telah menggeser pengetahuan lokal dan kepercayaan petani dalam mengatur waktu dan cara bercocok tanam mereka. Maraknya pembangunan irigasi teknis untuk meningkatkan frekuensi tanam dan produksi hasil pertanian telah menyebabkan tergerusnya pengetahuan lokal tentang 'perbintangan' yang digunakan sebagai pedoman untuk mengetahui musim dan curah hujan, misalnya pada Pronoto Mongso petani Jawa. Pedoman ini sangat penting untuk menentukan kegiatan petani, misalnya kapan mulai menyemai bibit dan menanam serta kapan waktu panen. Selain itu, maraknya penggunaan teknologi input pertanian dari bahan-bahan kimia, seperti pesitisa, insektisida dan herbisida, juga berimplikasi pada menurunnya penggunaan pengetahuan dan kearifan lokal dalam menanggulangi hama dan penyakit tanaman dengan predator alam.

Kemajuan teknologi pertanian di satu sisi sangat diperlukan untuk peningkatan produksi, namun di sisi lain penerapan teknologi mempunyai dampak negatif terhadap petani, usaha tani, dan sumber daya lahan serta lingkungan di sekitarnya. Kemajuan teknologi, baik dalam bentuk peralatan, seperti traktor dan pompa air, maupun input atau sarana produksi (saprodi) pertanian (pupuk, pestisida/herbisida) dari bahan kimia bermanfaat untuk meningkatkan frekuensi tanam, namun hal ini menyebabkan peningkatan kebutuhan akan air dan limbah pertanian yang mengakibatkan meningkatnya pencemaran air. Selain itu, perubahan ini tidak prospektif karena menjadikan ketergantungan masyarakat petani kepada pemerintah dan input pertanian yang tidak ramah lingkungan.

Kegiatan pembangunan dan modernisasi teknologi memberikan harapan akan peningkatan kesejahteraan 
bagi masyarakat, tetapi kalau tidak dilakukan secara bijak dan terencana akan memberikan hasil yang sebaliknya. Penerapan teknologi yang tidak ramah lingkungan akan mengancam keberlangsungan sumber daya alam dan mengikis tatanan sosial di masyarakat. Modernisasi dan globalisasi merupakan tantangan besar terhadap keberlangsungan kearifan lokal di Indonesia. Masuknya teknologi dan nilai-nilai baru menyebabkan perubahan perilaku dan budaya dalam pengelolaan sumber daya air di Indonesia, karena itu perlu dihadapi dan disikapi juga dengan arif.

Perilaku masyarakat yang tidak ramah terhadap lingkungan dan pengelolaan yang tidak tepat menjadi penyebab utama kerusakan sumber daya air dan mengancam keberlanjutan sumber daya tersebut. Permasalahan ini berkaitan erat dengan faktor ekonomi, terutama kemiskinan dan keserakahan, dan faktor non ekonomi, termasuk kurangnya pengetahuan dan informasi, dan kekurangpedulian masyarakat terhadap pentingnya pelestarian sumber daya alam tersebut. Sebagian anggota masyarakat memahami bahwa kegiatan mereka telah berdampak negatif terhadap kondisi air di sekitar lingkungannya, tetapi mereka tidak peduli terhadap dampak yang disebabkan oleh ulah mereka dan karena itu terus melakukan kegiatan yang merusak tersebut. Keserakahan juga menjadi alasan penting terjadinya perusakan sumber daya air, biasanya dilakukan oleh sekelompok kecil masyarakat yang punya modal atau pengusaha-pengusaha. Motif mereka berbeda dengan masyarakat desa yang miskin, yang pemilik modal/pengusaha-pengusaha inginkan adalah mendapatkan keuntungan sebesar-besarnya dengan cara mudah. Hal ini terutama terjadi di daerah-daerah yang (akan) menjadi pusat-pusat pembangunan dan kegiatan ekonomi di seluruh negeri ini.

Masuknya perusahaan-perusahaan kelapa sawit merupakan contoh pembukaan tutupan hutan secara besar-besaran yang berimplikasi pada rusaknya sumber daya air di berbagai daerah di Indonesia, seperti di Provinsi Jambi. Perusahaan-perusahaan tersebut mengkonversi hutan menjadi lahan monokultur kebun kelapa sawit yang menyebabkan degradasi ekosistem dan sumber daya air di daerah pasang surut. Selain itu, keberadaan kebun-kebun sawit yang sangat luas juga mengakibatkan penurunan atau bahkan gagalnya produksi padi di sawah-sawah di sekitar perkebunan tersebut dikarenakan sumber-sumber air yang sangat dibutuhkan untuk pertumbuhan padi sawah berkurang secara signifikan dan /atau air sangat asam karena tercampur atau terkontaminasi dengan pirit di lahan pasang surut. Pada musim hujan, meskipun air berlimpah, petani sawah tidak dapat memanfaatkan limpahan air dari saluran-saluran di sekitar kebun- kebun sawit, karena airnya asam, sedangkan pada musim kemarau akan kekurangan air/kekeringan.

\section{KESIMPULAN}

Masyarakat Indonesia dahulu hidup harmonis dengan alam dan sumber daya air di lingkungan sekitarnya. Kearifan lokal yang berkembang di masyarakat menjadi panduan bagi sikap dan tindakan mereka dalam memenuhi kebutuhan sehari-hari. Kearifan tersebut, ternyata telah memudar. Tulisan ini menginformasikan banyak tradisi masyarakat yang telah diabaikan dan tradisi lainnya sudah tinggal menjadi kenangan. Hal ini sangat disayangkan, karena dalam pengelolaan air, kearifan lokal mengandung nilai pelestarian sumber daya tersebut. Sumber daya air saat ini berada dalam kondisi yang memprihatinkan karena adanya peningkatan secara signifikan pemanfaatan air, polusi air, dan kegiatan eksploitasi secara berlebihan yang menyebabkan degradasi sumber daya alam dan lingkungan di sekitarnya.

Memudarnya kearifan lokal berkaitan erat dengan menurunnya solidaritas dan kebersamaan dalam kegiatan gotong royong di masyarakat, rasa kepemilikan bersama masyarakat terhadap sumber daya alam di daerahnya, dan berkurangnya hubungan yang harmonis antara sesama anggota masyarakat, sumber daya air dan lingkungan di sekitarnya. Tekanan penduduk terhadap air dan sumber daya alam mempunyai kontribusi yang besar, terutama peningkatan jumlah penduduk secara signifikan dan perilaku mereka yang merusak sumber daya dan lingkungan di sekitarnya. Kegiatan pembangunan dan modernisasi melalui proses globalisasi juga dijadikan alasan sebagai penyebab utama kerusakan sumber daya air. Penggunaan teknologi dan nilai-nilai baru terhadap sumber daya air telah berdampak signifikan terhadap terjadinya pergeseran perilaku dan budaya dalam pengelolaan sumber daya air tersebut.

Pengelolaan sumber daya air karena itu sangat diperlukan, namun saat ini pengelolaan lebih terfokus pada fungsi ekonomi, sedangkan fungsi sosial dan ekologi telah mengalami degradasi. Hal ini diindikasikan oleh lunturnya praktik pengelolaan air berbasis kearifan lokal yang menekankan pada aspek fungsi sosial dan ekologi dalam pengelolaan air. Modernisasi dan globalisasi merupakan tantangan besar terhadap keberlangsungan kearifan lokal di Indonesia. Pengelolaan sumber daya air yang berkelanjutan karena itu harus berakar dari hubungan yang harmonis dan berfungsinya sumber daya air dalam aspek ekonomi, sosial dan ekologi. 
Tulisan ini menghighlights pentingnya eksistensi kearifan lokal masyarakat dalam pengelolaan sumber daya air. Kearifan lokal harus dilestarikan dalam suatu masyarakat guna menjaga keseimbangan antara pemanfaatan sumber daya air dengan lingkungan dan sekaligus upaya pelestariannya. Tradisi masyarakat dalam mengelola air harus terus dipertahankan, menyeimbangkan dan menyelaraskan hubungan antara kehidupan sosial ekonomi dan preservasi sumber daya alam di lingkungan sekitarnya.

\section{DAFTAR PUSTAKA}

Aprianto, Y., Pardede, I.A., dan Fernando, E.R. 2008. "Kearifan Lokal dalam Mewujudkan Sumber Daya Air Yang Berkelanjutan. Bogor: Institute Pertanian Bogor.

Adnyana, I.G.N.S. 2003. 'Tantangan Pemerintah Daerah dalam Pengelolaan Sumber Daya Air yang Berkelanjutan'. Makalah disampaikan dalam Seminar Peran Budaya Lokal dalam Menunjang Sumber Daya Air yang Berkelanjutan. Kerjasama antara BAPPENAS dengan FAO-UN, Kuta Beach, Bali, 2 Oktober 2003.

Ardhana, G. 2005. Kearifan Lokal Tanggulangi Masalah Sosial Menuju Ajeg Bali. http://www.balipost.co.id/balipostcetak/2005/11/12 /o2.htm. diakses 14 November 2007.

Bappenas, BPS dan United Nations Population Fund. 2013. Proyeksi Penduduk Indonesia 2000-2025. Jakarta: BAPPENAS.

Dick, H. 1982: Survey of recent developments. Bulletin of Indonesian Economic Studies 18, 1-38.

Fox, J.J. 1991: Managing the ecology of rice production in Indonesia. In Joan, H., editor, Indonesia: resources, ecology, and environment. Singapore: Oxford University Press, 61-84.

Hidayati, D. 2012. Peran Radio dalam Peningkatan Pemahaman Petani dan Nelayan terhadap Perubahan Iklim. Bogor: PT Sarana Komunikasi Utama, hal 223 - 254.

Keraf, A.S. 2002. Etika Lingkungan. Jakarta: Penerbit Buku Kompas.

Mears, L.A. 1984: Rice and food self-sufficiency in Indonesia. Bulletin of Indonesian Economic Studies 20, 122-137.
Pawitan, H. 2011. Konsep Ekohidrologi sebagai Paradigma Baru Pengelolaan Sumber Daya Air Berkelanjutan. Makalah disajikan dalam KIPNAS X Thema: Pemanfaatan Ilmu Pengetahuan dalam Membangun Kemandiarian serta Kedaulatan Bangsa dan ditengah Perubahan Global. Jakarta, 8-10 November 2011.

Prasodjo, N.W. 2005. Pengetahuan Lokal dalam Pengelolaan Daerah Aliran Sungai Citanduy (Studi Desentralisasi Pengelolaan dan Sistem Tata Pemerintahan Sumber Daya ALam). Working Paper Series No.14. Jakarta: PSP-IPB dan Partnership for Governmence Reform in Indonesia - UNDP.

Octora, Y., Rompas, A., Subahani, E., dan Alfons, F. 2010. Kearifan Lokal dalam Pengelolaan Sumber Daya Alam di Kawasan Eks PLG. Palangkaraya: Walhi Kemitraan Partnership.

Soeprobowati, T.R. 2010. Ekohidrologi Konsep Pengelolaan Lingkungan Berkelanjutan. BIOMA No.1, Vol 12, Juni 2010, hal 13-19.

Sulastryono. 2009. Nilai-nilai Kearifan Lokal dalam Pengelolaan Sumber Daya Air di Telaga Omang dan Ngloro, Kecamatan Saptosari, Gunung Kidul, Yogyakarta. Mimbar Hukum, Volume 21, Nomor 2, Juni 2009, hal: 203-408.

Sunaryo dan Joshi. L. 2003. Peranan Pengetahuan Ekologi Lokal dalam Sistem Agroforestri. Bogor: World Agroforestry Centre (ICRAF).

Sutawan, N. 2003. 'Kearifan Lokal dalam Pengelolaan Sumber Daya Air dan Upaya-upaya Pemberdayaan Subak di Bali'. Makalah Seminar Peran Budaya Lokal dalam Menunjang Sumber Daya Air yang Berkelanjutan. Kerjasama antara BAPPENAS dengan FAO-UN, Kuta Beach, Bali, 2 Oktober 2003.

Yamani, M. 2011. Strategi Perlindungan Hutan Berbasis Hukum Lokal di Eman Komunitas Adat Daerah Bengkulu. Jurnal Hukum No.2 Vol. 18, April 2011, hal 175-192. 